\title{
MODEL PEMBELAJARAN INVESTIGASI KELOMPOK UNTUK MENGANALISIS BENTANG ALAM HASIL GAYA GEOLOGI MELALUI PENGGUNAAN GOOGLE EARTH
}

\section{Groups Investigation Learning Model to Analyze the Landscape Effect of Geological Processes Using Google Earth}

\author{
Dwi Angga Oktavianto \\ Guru Geologi Pertambangan SMK Negeri 1 Binuang \\ Jl. Oscar-Blok O, Pualam Sari, Kec. Binuang, Kab.Tapin, Kalimantan Selatan, Indonesia \\ e-mail: oktavianto.angga7@gmail.com
}

\begin{abstract}
ABSTRAK: Penelitian ini bertujuan untuk meningkatkan keterampilan berpikir kritis siswa agar dapat melakukan analisis terhadap bentang alam hasil dari gaya geologi. Tindakan yang dilakukan ialah dengan memanfaatkan Google Earth melalui model pembelajaran Investigasi Kelompok. Penelitian ini menggunakan metode penelitian tindakan kelas. Penelitian dilakukan pada kelas X Geology Pertambangan SMK Negeri 1 Binuang dengan jumlah subjek 33 siswa. Data hasil penelitian pada siklus-2 menunjukkan adanya peningkatan kemampuan beprikir kritis dibandingkan dengan siklus-1 dmanasiswa dengan tingkat berpikir (1) kurang kritis, dari yang semula 70\% menjadi 12\%; (2) cukup kritis, dari 15\% menjadi 33\%; (3) berpikir kritis, dari 15\% menjadi 46\%; dan (4) berpikir sangat kritis, dari yang semula tidak ada menjadi $9 \%$.
\end{abstract}

Kata Kunci: Google Earth, investigasi kelompok, berpikir kritis, bentang alam, gaya geologi.

ABSTRACT: This study aims to improve students' critical thinking skills so that they can conduct an analysis of the landscape resulting from geological forces. The action taken is to utilize Google Earth through the Group Investigation learning model. This research uses classroom action research methods. The study was conducted in class $X$ Mining Geology of SMK Negeri 1 Binuang with a total of 33 student subjects. The data show thatfrom cycle-2 indicates an increasein students' order thinking skills, whichare: 1) less critical, from $70 \%$ to $12 \%$; 2) quitecritical, from $15 \%$ to $33 \%$; 3) critical, from $15 \%$ to $46 \%$; and 4) highly critical, from 0 to $9 \%$.

Keywords: Google Earth, group investigation, criticalthinking, landscapes, geological process. 


\section{PENDAHULUAN}

Teknologi menjadi faktor utama yang mempengaruhi kehidupan masyarakat di masa sekarang dan masa-masa yang akan datang. Sebagai bagian dari masyarakat, siswa juga merupakan pengguna teknologi. Mereka bahkan dapat lebih baik dalam menggunakan teknologi, dibandingkan orang yang lebih tua. Guru sebagai fasilitator dalam pembelajaran sudah sepatutnya memfasilitasi siswa untuk memanfaatkan perkembangan teknologi. Bukan malah memberikan pembatasan penggunaan teknologi, namun tidak memberikan solusi untuk memanfaatkannya.

Salah satu cara memanfaatkan teknologi ialah menghadirkan teknologi dalam pembelajaran di kelas. Teknologi yang digunakan harus disesuaikan dengan karakteristik materi dan tujuan pembelajaran yang akan dicapai. Kesesuaian tersebut dapat membuat siswa lebih semangat dalam belajar, meningkatkan peran siswa selama proses pembelajaran, dan efektif dalam penyampaian materi sehingga mudah diterima oleh siswa.

Siswa Jurusan Geologi Pertambangan di SMK Negeri 1 Binuang belum mampu melakukan memanfaatkan teknologi dalam menganalisis bentang alam hasil gaya geologi. Hal ini ditunjukkan dari pengamatan guru selama mengajar di jurusan tersebut. Siswa setelah melihat gambar salah satu bentang alam dari citra penginderaan jauh, mereka belum mampu untuk menyebutkan nama dari bentang alam tersebut dan tidak dapat menjelaskan bagaimana bentang alam tersebut dapat terjadi. Hal ini menunjukkan bahwa siswa belum menguasai keterampilan yang seharusnya dimiliki seorang yang belajar ilmu kebumian. Selain itu siswa juga terlihat mengalami kesulitan dalam mempertahankan sebuah jawaban ketika terjadi sebuah diskusi. Argumen mereka mencermikan kemampuan berpikir kritis yang masih rendah. Kedua contoh tersebut tentunya akan berdampak pada tingkat analisis lanjut dari kompetensi menganalisis bentang alam hasil gaya geologi.

Permasalahan yang terjadi pada siswa Jurusan Geologi Pertambangan perlu dicarikan jalan keluar. Salah satu jalan keluar yang dapat ditempuh adalah melalui perbaikan proses pembelajaran. Perbaikan proses pembelajaran dapat dimulai dengan memilih model pembelajaran yang sesuai, serta terbukti mampu untuk mengembangkan keterampilan menganalisis. Selain itu, juga perlu didukung adanya media pembelajaran yang dapat digunakan dalam upaya meningkatkan keterampilan menganalisis bentangalam hasil gaya geologi. Kedua, penggunaan media pembelajaran yang sesuai dengan konten materi bentang alam hasil gaya geologi. Media pembelajaran berfungsi untuk menghadirkan konteks dunia nyata dalam ruang kelas.

Pembelajaran geologi dapat dilakukan dengan pemanfaatan teknologi geospasial. Geologi hampir sama dengan geografi, yakni sama-sama merupakan bidang kajian ilmu kebumian. Salah satu teknologi geospasial yang dapat dimanfaatkan ialah Google Earth (Oktavianto, Handoyo \& Sumarmi, 2017). Pembelajaran yang memadukan suatu model dan dengan memanfaatkan Google Earth sebagai alat bantu pembelajaran ternyata dapat meningkatkan keterampilan berpikir spasial siswa. Hal ini memberi peluang terhadap penelitian ini, bahwa Google Earth juga dapat meningkatkan berpikir kritis siswa. Namun perlu memilih model pembelajaran yang tepat.

Dari identifikasi masalah pada latar belakang di atas dapat dirumuskan masalah yang menjadi fokus pembahasan, yaitu: "Bagaimana pemanfaatan Google Earth melalui penerapan model pembelajaran GI pada kelas XI Geologi Pertambangan dapat meningkatkan keterampilan berpikir kritis siswa dalam menganalisis bentangalam hasil gaya geologi?"

Keterampilan menganalisis merupakan keterampilan yang masuk dalam pengetahuan berbentuk dimensi metakognisi (Lin, Hou, Wang dan Chang, 2013). Hal ini berarti bahwa keterampilan menganalisis dapat dikategorikan 
Higher Order Thinking Skills (HOTS). Brookhart (2010) identifies definitions of higher-order thinking as falling into three categories: (1) those that define higher-order thinking in term of transfer, (2) those that define it in terms of critical thinking, and (3) those that define it in termof problem solving.

Pendapat Brookhart dapat diartikan bahwa definisi pemikiran tingkat tinggi dapat dibagi ke dalam tiga kategori: (1) definisi transfer, (2) definisi dalam hal berpikir kritis, dan (3) definisi dalam hal pemecahan masalah. HOTS dalam keterampilan menganalisis pada penelitian ini dibatasi mengenai upaya peningkatan berpikir kritis siswa.

Peningkatan berpikir kritis siswa dalam pembelajaran dapat melalui dua tindakan. Melalui perbaikan model pembelajaran dan melalui penggunaan media pembelajaran. Perbaikan model pembelajaran dapat dilakukan dengan memilih model-model pembelajaran yang mampu meningkatkan berpikir kritis siswa dalam pembelajaran kebumian (geologi, geomorfologi, dan geografi). Sedangkan media pembelajaran yang digunakan dapat berupa teknologi geospasial.

Model-model pembelajaran tersebut antara lain: Group Investigation (Agustina, 2017), Project-Based Learning (Hayuna, Budijanto \& Utomo, 2018), Problem-Based Learning (Sari, Jayanti \& Jamil, 2016). Banyak model pembelajaran lainnya yang dapat digunakan untuk meningkatkan berpikir kritis, namun perlu dikaji lebih lanjut model mana yang cocok untuk digunakan dalam pembelajaran menganalisis bentang alam hasil gaya geologi.

Berpikir kritis merupakan bagian dari kemampuan kognitif. Tiga level atas domain berpikir yang disampaikan Bloom dalam taxonominya (analisis, sintesis, dan evaluasi) sering dimaknai sebagai berpikir kritis, terkadang ditambah dengan komprehensif dan aplikasi (Dwyer, Hogan, dan Stewart, 2014). Namun, pendapat ini hanya berdasarkan teori, padahal itu belum menunjukkan sebuah tingkatan, dan masing- masing memiliki keterkaitan. Sebagai contoh, sintesis dan evaluasi biasanya dapat diartikan juga sebagai analisis.

Tes berpikir kritis dimungkinkan untuk berbagai variasi tujuan. Semakin tinggi biayanya dan semakin terbatasnya anggaran, semakin sedikit siswa yang bisa dites keterampilan berpikir kritisnya. Secara khusus, kelengkapan alat untuk menguji berpikir kritis untuk hal yang luas terhambat biaya yang besar.

Sejumlah tes yang dipublikasikan telah fokus pada berpikir kritis. Hampir semua tes berbentuk pilihan ganda. Keuntungannya yaitu dalam efisiensi biaya, tapi sebenarnya tes pilihan ganda tidak memberi gambaran utuh terhadap berpikir kritis (Halpern, 2013).

Penelitian dan pengembangan tes berpikir kritis harus lebih banyak lagi dilakukan. Alternatif yang layak mencakup penambahan permintaan pembenaran ke beberapa item pilihan, pengujian esai dengan berbagai tingkat struktur, dan kinerja penilaian. Hal itu jauh lebih mahal dari pengujian yang berupa tes pilihan ganda bila digunakan dalam skala besar. Tapi dalam skala kecil, tes uraian menawarkan alternatif yang layak dalam hal validitas dan biaya. Namun, waktu yang dibutuhkan juga lebih banyak daripada menilai berpikir kritis melalui tes pilihan ganda.

Tujuan pembuatan soal berpikir kritis adalah: (1) melakukan diagnosistingkat berpikir kritis siswa; (2) memberikan umpan balik terhadap siswa tentang keterampilan berpikir kritisnya; (3) memotivasi siswa agar semakin baik berpikir kritisnya; (4) memberikan informasi kepada guru apakah pembelajarannya selama ini mampu meningkatkan berpikir kritis; (5) untuk meneliti tema-tema berpikir kritis melalui instrumen tes; (6) untuk memberikan saran kepada siswa ketika hendak melanjutkan sekolah kejenjang yang lebih tinggi; dan (7) memberikan gambaran tentang keterampilan berpikir kritis siswanya (Stupple, Maratos, \& Elander, 2017).

Tes uraian terbuka biasanya memiliki tingkat kesulitan yang tinggi. Tes berpikir kritis yang dibuat Ennis \& Weir merupakan jenis tes uraian terbuka (Agustina, 2017). Dalam 
menjawab soal jenis ini, siswa sering mengalami kesulitan saat berargumen untuk mempertahankan jawabannya. Ini malah bagus untuk menilai kemampuan berpikir kritis siswa. Tes ini cocok digunakan untuk sekolah tingkat atas ataupun tingkat perguruan tinggi. Namun, cocok untuk tes berpikir kritis.

Membuat soal secara mandiri mungkin akan lebih baik. Namun hal ini perlu dilakukan beberapa kali uji coba sebelum soal benar-benar digunakan secara luas. Soal yang dibuat harus memenuhi syarat valid dan relaibel (Stupple, Maratos, \& Elander, 2017). Soal yang dibuat sendiri oleh guru memiliki keunggulan karena mereka yang paling paham tentang kondisi siswanya.

Tabel 1. Indikator Kemampuan Berpikir Kritis

\begin{tabular}{|c|c|c|}
\hline No & $\begin{array}{l}\text { Kemampuan } \\
\text { Berpikir Kritis }\end{array}$ & Indikator \\
\hline 1 & $\begin{array}{l}\text { Merumuskan } \\
\text { masalah }\end{array}$ & $\begin{array}{l}\text { Merumuskan } \\
\text { permasalahan dan } \\
\text { memberi arah untuk } \\
\text { memperoleh } \\
\text { jawaban }\end{array}$ \\
\hline 2 & $\begin{array}{l}\text { Memberikan } \\
\text { argumen }\end{array}$ & $\begin{array}{l}\text { Memberikan } \\
\text { argumen disertai } \\
\text { saran }\end{array}$ \\
\hline 3 & $\begin{array}{l}\text { Melakukan } \\
\text { deduksi }\end{array}$ & $\begin{array}{l}\text { Memberikan } \\
\text { penjelasan dimulai } \\
\text { dari hal umum ke } \\
\text { khusus }\end{array}$ \\
\hline 4 & Melakukan induksi & $\begin{array}{l}\text { Membuat simpulan } \\
\text { terkait masalah }\end{array}$ \\
\hline 5 & $\begin{array}{l}\text { Melakukan } \\
\text { evaluasi }\end{array}$ & $\begin{array}{l}\text { Melakukan evaluasi } \\
\text { berdasarkan fakta }\end{array}$ \\
\hline 6 & $\begin{array}{l}\text { Memutuskan dan } \\
\text { melaksanakan }\end{array}$ & $\begin{array}{l}\text { Menentukan solusi } \\
\text { alternatif dari } \\
\text { masalah untuk } \\
\text { dapat direncanakan } \\
\text { dan dilaksanakan }\end{array}$ \\
\hline
\end{tabular}

Sumber: Modifikasi Berpikir Kritis Ennis (Agustina, 2017)

Model pembelajaran Group Investigation (GI) terbukti mampu meningkatkan keterampilan menganalisis. GI sesuai untuk pembelajaran yang berhubungan dengan keterampilan menganalisis informasi dalam upaya penyelesaian masalah yang bersifat multi-aspek (Listiana, 2013). Penelitian lain menjelaskan bahwa hasil belajar siswa yang menggunakan $\mathrm{Gl}$ lebih tinggi keterampilan berpikir kritisnya dibandingkan siswa yang diajarkan dengan pembelajaran konvensional (Budiastara, Sudana \& Arcana, 2015). GI yang sudah terbukti tersebut akan diterapkan pada kelas X Geologi Pertambangan SMK N 1 Binuang.

GI sebagai sebuah pembelajaran mempunyai empat elemen dasar. Elemen tersebut adalah "investigation, interaction, interpretation, dan intrinsic" (Thibout, 2017). Empat komponen tersebut perlu diuji keterkaitannya. Bagaimana keempat elemen tersebut dapat merubah pembelajaran konvensional menuju pembelajaran kooperatif.

Ahli yang lain berpendapat tentang $\mathrm{GI}$ sesuai kapasitasnya. Slavin (2015) menyatakan bahwa GI merupakan sebuah rencana kelompok yang bertujuan memberikan dorongan keterlibatan siswa selama proses pembelajaran agar berjalan optimal. GI berdasarkan pembelajaran kooperatif dengan susunan sedemikian rupa, bertujuan agar siswa memiliki peran yang rinci dalam sebuah kelompok.

GI sebagaimana model pembelajaran lainnya juga memiliki sintaks dalam keterlaksanaannya. Sintaks ini perlu diketahui agar nantinya penerapan Gl dapat sesuai dengan tujuan pembelajaran. Sintaks pembelajaran GI berdasarkan Sumarmi (2012) adalah sebagai berikut: (1) pengorganisasian kelompok dan melakukan indentifikasi topik, (2) kelompok melakukan perencanaan, (3) kelompok melakukan penyelidikan, (4) kelompok melakukan analisis hasil dan menyiapkan laporan, dan (5) kelompok menyajikan laporan.

GI merupakan pembelajaran kooperatif yang paling kompleks. GI sangat cocok digunakan untuk materi yang memerlukan berbagai perspektif, permasalahan yang dimunculkan kemudian diklasifikasi oleh masing-masing kelompok dan dicarikan solusi. GI sangat baik digunakan untuk 
sekolah tingkat menengah pertama sampai menengah atas dengan kemampuan akademik yang beragam.

GI sebagai sebuah pembelajaran mempunyai empat elemen dasar. Elemen tersebut adalah "investigation, interaction, interpretation, dan intrinsic" (Thibout, 2017). Empat komponen tersebut perlu diuji keterkaitannya. Bagaimana keempat elemen tersebut dapat merubah pembelajaran konvensional menuju pembelajaran kooperatif?

Keunikan dari GI adalah tentang keempat elemen yang saling berhubungan secara simultan. Apabila di antara keempat elemen tersebut ada yang hilang, maka Gl tidak akan berjalan. Perlu menjadi catatan bahwa keempat elemen harus dapat dijalankan dengan baik.

Investigasi, elemen pertama ini merupakan ciri khas dan secara umum arahan mendasardari GI. Investigasi merupakan kegiatan awal dari sebuah kelompok, yaitu mendesain sebuah proyek penelitian. Mereka juga harus merancang proses, baik sebagai sebuah kelompok maupun individu dalam kelompok untuk memperoleh informasi. Informasi yang dimaksud disinididapat dari berbagai sumber yang relevan untuk menjadi dasar pemecahan masalah. Inti dari elemen pertama ini adalah "learning by discovery"; bedanya, siswa hanya menemukan ide dasar dari berbagai sumber informasi dan kemudian memilih pemeccahan masalah secara bersama.

Interaksi merupakan komponen dalam GI yang menjadi ciri utama pembelajaran kooperatif. Semua pembelajaran kooperatif menggunakan konsep "give-and-take" dan simbiosis mutualisme antar anggota kelompok (Slavin, 2015). Interaksi yang terjadi di GI merupakan cara untuk menguji informasi yang didapat dari berbagai sumber melalui tukar menukar gagasan, diskusi mengenai informasi tersebut dan kemudian mengambil mufakat secara bersama. Interaksi dalam kelompok kecil seperti GI mampu untuk meningkatkan metakognisi siswa (Pae, Sears dan Maeda, 2014).

Interpretasi merupakan kegiatan dalam GI yang memaknai informasi yang didapat; kemudian dari pemaknaan tersebut dapat ditarik kesimpulan. Interpretasi merupakan gabungan dari kegiatan, fakta, pengalaman, dan perasaan. Interpretasi dalam GI dapat pula diartikan sebagai proses negosiasi antara tiap-tiap anggota kelompok yang mempunyai informasi yang berbeda untuk mendapatkan gambaran secara utuh (Sharan, 2015).

Intrinsik dalam GI lebih tepat disebut motivasi intrinsik. Setiap individu yang ada dalam kelompok memiliki hal ini dengan level yang berbeda. Dalam GI, motivasi intrinsik anggota kelompok yang tinggi dapat ditularkan kepada anggota kelompok yang motivasi intrinsiknya rendah. Dengan demikian, semua angggota kelompok akan memiliki motivasi yang tinggi.

Penerapan GI sangat tergantung pada kondisi lingkungan sekolah. Lingkungan sekolah menyangkut sarana-prasarana, Kepala Sekolah, dan sesama guru. GI harus mendapat dukungan dari semua pihak disekolah. Penggunaan GI perlu kerjasama beberapa guru, saling melakukan observasi untuk mendapatkan umpan bailk, dan menjadi asisten satu dengan yang lain (Sharan, 2015).

GI dapat memanfaatkan teknologi dalam pembelajaran. GI dapat digunakan pada topik yang sangat luas melalui pemanfaatan teknologi, promosi peer interaksi, membangun kemampuan interpretasi, dan membangun perspektif sosial. Kedepan GI harus memanfaatkan perkembangan teknologi.

Ada berbagai macam pengertian GI menurut para ahli. Model GI merupakan model pembelajaran kooperatif dengan tingkatan sangat kompleks. Pandangan ini terjadi karena GI mengkombinasikan berbagai pemikiran, yakni mengenai teori konstruktivis, pembelajaran demokratis, dan kooperatif. Menurut konstruktivis, GI memberikan kesempatan sebesar-besarnya kepada peserta didik agar berpartisipasi secara langsung dalam proses pembelajaran.

Pembelajaran GI dapat diartikan sebagai pengarahan kepada siswa untuk melakukan inkuiri dengan cara kooperatif (Sudarsana, 2018). Siswa belajar karena mereka ingin mengerti, pembelajaran yang diarahkan siswa secara intrinsik bermanfaat dan sangat berbeda dari pembelajaran instrumental dimana tujuannya adalah untuk mendapatkan keberpihakan, persetujuan, atau investigasi topik.

Ahli yang lain,Slavin (2015) menyatakan bahwa GI merupakan sebuah rencana kelompok yang bertujuan memberikan dorongan keterlibatan siswa selama proses pembelajaran agar berjalan optimal. GI berdasarkan pembelajaran kooperatif dengan susunan sedemikian rupa, untuk tujuan agar siswa memiliki peran yang rinci dalam sebuah kelompok. Peran yang rinci dari siswa memberikan 
mereka gambaran yang jelas tentang apa yang mereka lakukan, sehingga menjadikan siswa lebih percaya diri dan memaknai kegiatan belajar sebagai proses yang harus dilalui. Hal ini penting bagi perkembangan kemampuan berpikir siswa.

GI terbentuk dari kelompok-kelompok kecil pada sebuah kelas yang menuntun dan memberikan dorongan kepada siswa agar berpartisipasi penuh dalam pembelajaran. GI menuntut siswa agar mampu memiliki keterampilan yang bagus selama berkomunikasi. Hasil akhir GI yaitu sumbangan ide yang berasal dari semua anggota kelompok serta mengasah keterampilan intelektualitas peserta didik jika dibanding belajar secara individu.

Agustina (2017) mengemukakan, GI merupakan strategi pembelajaran berkelompok yang memposisikan peserta didik didalam sebuah kelompok,kemudian melakukan investigasi secara mendalam pada sebuah tema yang mereka tentukan. Dari berbagai pendapat di atas disimpulkan, fokus utama Gl adalah dalam hal investigasi terhadap sebuah topik tertentu. Setelah ditentukan model pembelajaran yang digunakan, kemudian memilih media pembelajaran.

Media pembelajaran yang dapat meningkatkan kemampuan berpikir dalam ilmu kebumian ialah media pembelajaran berbasis teknologi geospasial. Salah satu teknologi geospasial yang dapat digunakan adalah Digital Earth atau Virtual Globe. Digital Earth sangat baik digunakan sebagai media pembelajaran ilmu kebumian. Geologi sebagai salah satu ilmu kebumian berarti dapat dipelajari dengan digital earth. Perubahan bentang lahan dapat diketahui melalui google earth (Sidhu, Pebesma, \& Camara, 2018). Hal ini memungkinkan google earth dapat pula digunakan untuk mempelajari bentang alam. Hal ini didukung oleh penelitian Yu \& Gong (2010) yang menyatakan bahwa google earth sebagai virtual globe dapat digunakan untuk belajar menganalisis dan mendeskripsikan perubahan lingkungan.

Sejak tahun 2005, para pendidik telah mengintegrasikan Google Earth ke dalam kelas (Blank, Almquist, Estrada, \& Crews, 2016). Namun, masih jarang yang menggunakannya untuk meningkatkan berpikir kritis. Xiang dan Liu (2016) mengeksplorasi fungsi dan sumber daya Google Earth untuk kegiatan pembelajaran di kelas. Hasil penelitian Xian dan Liu di atas sejalan dengan penelitian Oktavianto\& Suyatno
(2018). Mereka membagikan pengalaman tentang penggabungan teknologi geospasial dengan sebuah model pembelajaran dalam mengembangkan kemampuan membaca peta dalam sebuah rencana pelajaran geografi di SMA. Hasil dari penelitian menunjukkan bahwa siswa mudah memahami pertanyaan dan menunjukkan keyakinan dalam jawaban. Suatu kegiatan yang menggabungkan Global Positioning System (GPS) dan Google Earth menciptakan pembelajaran yang menarik pengalaman untuk siswa kelas $X$ SMA. Kegiatan ini meningkatkan keterampilan praktis dalam teknologi dan meningkatkan keterampilan siswa dalam membaca dan interpretasi peta (Oktavianto \& Suyatno, 2018). Demikian pula, sebuah studi lain (Blank, Almquist, Estrada, \& Crews, 2016) mengakui bahwa pembelajaran berorientasi spasial lebih mudah menarik perhatian siswa dengan bantuan Google Earth. Eksperimen secara nyata dengan Google Earth menciptakan motivasi dan antusiasme di kalangan siswa.

Google Earth yang berupa teknologi antarmuka meyediakan peluang kepada siswa untuk belajar ilmu baru; bersamaan dengan itu, siswa juga meningkat pengetahuan geografisnya dan keterampilan menggunakan teknologi (Guertin \& Neville, 2011). Google Earth mendukung pemikiran spasial dan juga mengembangkan keterampilan analitis kritis (Ratinen \& Keinonen, 2011). Google Earth memungkinkan siswa untuk menjelajahi bumi dengan cara yang dinamis dan interaktif, membantu mereka memahami dan mempelajari konteks spasial lokal mereka dalam kaitannya dengan konteks global, dengan cara yang berorientasi spasial, menghibur dan bermakna (Ratinen \& Keinonen, 2011). Penelitian Demirci, Karaburun, \& Kilar (2013) menyatakan bahwa sebagian besar siswa yang belajar dengan Google Earth merasa proses pembelajarannya menyenangkan, bermanfaat dan menarik.

Latar belakang dan kajian pustaka di atas menjadi dasar dilakukannya penelitian ini. Model pembelajaran yang berpusat kepada siswa diharapkan mampu menjadikan setiap siswa lebih aktif. Keaktifan siswa ditunjang dengan teknologi. Pemanfaatan teknologi sebagai media pembelajaran diharapkan dapat meningkatkan minat dan keterampilan berpikir kritis siswa. Pemilihan teknologi pun tidak sembarang teknologi, namun berupa teknologi geospasial berupa Google Earth. 


\section{METODA}

Penelitian yang dilakukan merupakan jenis Penelitian Tindakan Kelas (PTK). PTK dipilih sebagai metode penelitian karena masalah yang dihadapi di dalam kelas perlu dicarikan sebuah perlakuan (tindakan) agar masalah yang terjadi dapat diselesaikan. PTK yang dijadikan acuan ialah desain dari Naish. Desain PTK tersebut adalah sebagai berikut.

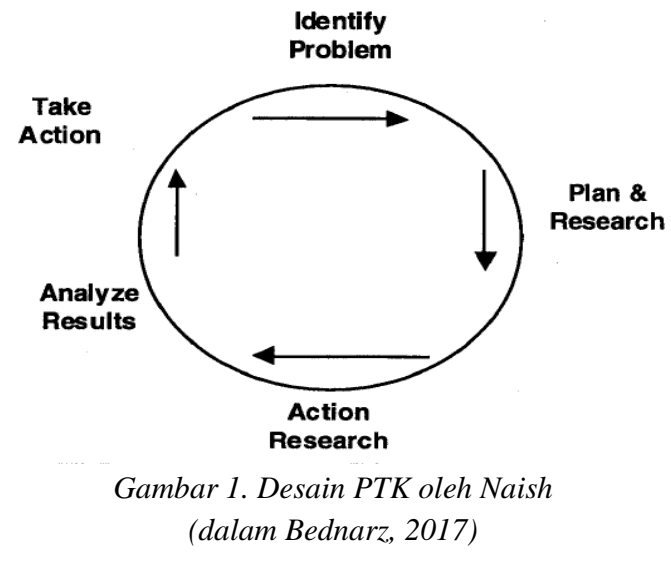

Siklus PTK di atas memiliki limalangkah. Kelima langkah dalam siklus PTK tersebut sangat penting. Langkah pertama guru mengidentifikasi masalah yang berkaitan dengan kondisi siswa pada kelas X Geologi Pertambangan. Guru harus memilih masalah yang spesifik dari berbagai permasalahan yang terjadi. Permasalahan yang diteliti kali ini adalah mengenai rendahnya kemampuan berpikir kritis siswa. Selanjutnya, guru mengamati kembali informasi yang berhubungan dengan masalah yang akan diteliti.

Langkah kedua ialah mengembangkan rencana tindakan yang akan dilakukan untuk mengatasi masalah. Rencana tindakan berupa pembuatan silabus dan Rencana Pelaksanaan Pembelajaran (RPP); selain itu, guru juga perlu menyiapkan siswa agar dapat menggunakan Google Earth. Hal ini dilakukan guru dengan melakukan tutorial penggunaan Google Earth. Guru dalam pembelajaran mengelompokkan siswa menjadi 8 kelompok. Hal ini dimaksud agar siswa melakukan investigasi terhadap konten secara berkelompok. Ini merupakan inti dari pembelajaran Group Investigation.

Setelah memperoleh berbagai informasi, guru di langkah ketiga melakukan tindakan yang dapat mengatasi masalah pada kelas. Guru dalam melaksanakan tindakan memerlukan bantuan seorang pengamat untuk mengamati proses pembelajaran yang terjadi.

Langkah keempat, guru melakukan analisis mengenai hasil observasi yang ditemukan oleh pengamatdansekaligus menarik kesimpulan dari proses pembelajaran yang telah dilaksanakannya. Dalam sintaks ini, guru juga memperhatikan data hasil tes pada akhir siklus. Tes akhir siklus mengkategorikan siswa ke dalam 4 kelompok, yaitu kategori sangat kritis apabila nilai siswa $81,25<X<100$, kategori kritis $62,50<X<81,25$, kategori cukup kritis $43,75<X<62,50$, dan kategori kurang kritis 25< X 43,75. Keberhasilan PTK berpedoman pada jumlah siswa yang masuk kategori sangat kritis dan kritis lebih banyak dibandingkan siswa yang masuk kategori cukup kritis dan kurang kritis.

Langkah kelima, guru melakukan tindakan lanjutan yang didasarkan atas hasil analisis dan kesimpulan yang didapat pada siklus pertama.

Penelitian ini dilakukan di SMK Negeri 1 Binuang. Penerapan model pembelajaran Group Investigation dilaksanakan pada Kelas $X$ Geologi Pertambangan. Materi yang dijadikan sebagai materi pelajaran adalah gaya geologi. PTK ini terdiri dari dua siklus, yaitusiklus-1 pada 7 Februari 2019 selama 5 jam pelajaran dan Siklus-II pada 14 Februari 2019 juga selama 5 jam pelajaran.

\section{HASIL DAN PEMBAHASAN}

\section{Siklus-1 (7 Februari 2019) Identifikasi Masalah}

Masalah yang terjadi di kelas X Geologi Pertambangan ialah rendahnya keterampilan berpikir kritis siswa. Hal ini teramati oleh guru selama semester ganjil tahun pelajaran 2018/2019. Guru di semester ganjil juga tidak memanfaatkan media pembelajaran berbasis teknologi. Selain itu, guru juga masih sering 
menggunakan model pembelajaran yang belum berpusat pada siswa. Permasalahan tersebut kemudian mendorong guru di semester genap ini untuk melakukan PTK agar keterampilan berpikir kritis siswa yang rendah menjadi lebih baik.

\section{Perencanaan}

Guru merencanakan PTK ini dengan mengaplikasikan pembelajaran Dasar-dasar Geologi pada materi gaya geologi melalui penggunaan model pembelajaran $\mathrm{Gl}$ dan memanfaatkan Google Earth. Hal ini tertuang dalam Rencana Pelaksanaan Pembelajaran (RPP).

RPP yang dibuat di dalam kegiatan inti pembelajaran menggunakan Sintaks-sintaks yang ada pada pembelajaran GI, yaitu sebagai berikut.

1. pengorganisasian kelompok dan melakukan indentifikasi topik, guru membagi kelas menjadi delapan kelompok dengan topik gaya geologi;

2. kelompok melakukan perencanaan, tiaptiap kelompok menginstal Google Earth pada masing-masing laptopnya, dan kemudian memilih fokus pada gaya geologi endogen ataupun eksogen;

3. kelompok melakukan penyelidikan melalui pengambilan gambar citra bentang alam dari Google Earth yang berupa gaya eksogen atau endogen sesuai dengan topik yang mereka pilih;

4. kelompok melakukan analisis hasil kumpulan citra bentangalam dan menyiapkan laporan, menyusun kumpulan gambar citra bentang alam tersebut ke dalam file berbentuk powerpoint, tiap-tiap slide powerpoint berisi sebuah gambar citra bentang alam serta deskripsi singkat gaya geologi yang terjadi; dan

5. kelompok menyajikan laporan dalam bentuk presentasi powerpoint di depan kelas.

Google Earth digunakan pada sintaks ketiga. Penggunaan Google Earth pada sintak ini merupakan bentuk investigasi. Investigasi dilakukan secara berkelompok, sehingga dalam sintaks tiga ini juga ditekankan pentingnya interaksi antar anggota kelompok. Siswa saling berargumen mengenai gaya geologi yang ada pada citra Google Earth.

RPP yang dibuat juga memuat lima soal uraian untuk mengukur tingkat berpikir kritis siswa. Lima soal ini bersumber dari indikator berpikir kritis. Soal uraian dipilih karenasoal jenis ini lebih tepat digunakan untuk mengukur keterampilan berpikir kritis siswa.

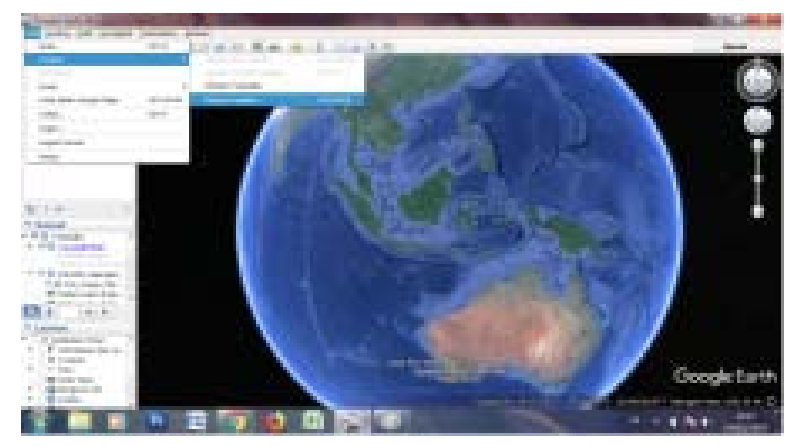

Gambar 2. Menyimpan Citra Google Earth (Sintaks 3 GI)

\section{Tindakan}

RPP yang telah dibuat, diterapkan dalam pembelajaran di kelas $X$ Geologi Pertambangan. Sintaks-1 membagi kelompok dan menentukan topik dilakukan guru dengan membagi siswa berdasarkan heterogenitas kelas. Hal yang menjadi prasayarat dalam pembentukan kelompok ialah salah seorang anggota kelompok harus memiliki laptop. Selanjutnya, mengenai gender dalam satu kelompok diusahakan terdiri dari laki-laki dan perempuan. Selain itu, guru juga mengelompokkan siswa dengan kemampuan akademik yang beragam, dengan tujuan agar siswa yang pandai dapat membantu dan memberi motivasi kepada siswa yang kurang pandai. Tingkat kepandaian ini didasarkan pada nilai siswa semester ganjil.

Sintaks-2 perencanaan yang dilakukan siswa dimulai dengan menginstal aplikasi Google Earth; penginstalan menghabiskan waktu sekitar 30 menit sehingga perlu pengkondisian suasana kelas agar tetap kondusif. Kemudian, tiap kelompok menentukan gaya geologi apa yang akan 
mereka selidiki dan analisis. Gaya geologi terdiri dari dua, yakni gaya endogen dan gaya eksogen. Setiap kelompok memilih salah satu gaya geologi tersebut. Hal ini diharapkan dapat memacu semangat mereka dalam pembelajaran, karena gaya geologi yang mereka pilih tentulah merupakan materi pelajaran yang menurut mereka menarik.

Sintaks-3, siswa melakukan pencarian bentangalam yang sesuai dengan gaya geologi yang mereka pilih. Setelah gambar tersebut muncul, kemudian tampilan pada google earth diperbesar agar gambar citra menjadi jelas. Setelah itu, siswa melakukan penyimpanan gambar dengan cara mengKlik menu File pada toolbar, dilanjutkan sorot menu Simpan, arahkan pada Simpan Gambar. Cara yang lebih cepat dapat dilakukan dengan meng-Klik Ctrl + Alt $+\mathrm{S}$.

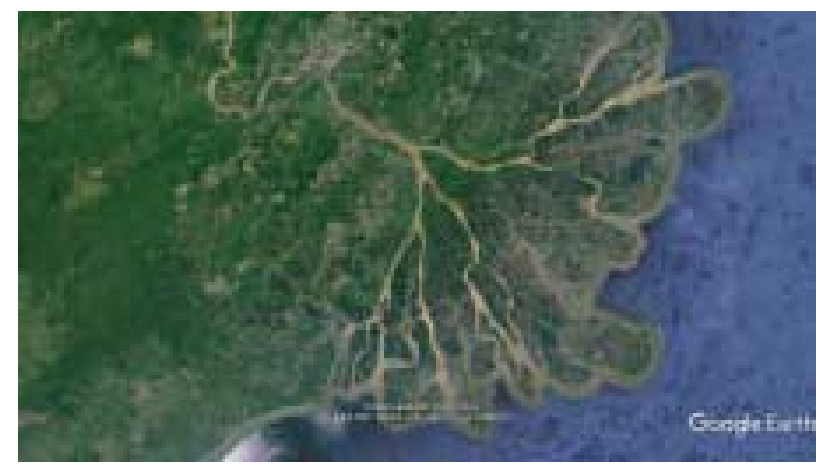

Gambar 3. Citra bentangalam Google Earth

Sintaks-4, siswa menganalisis bentang alam tersebut. Gambar 2 merupakan hasil dari salah satu kelompok. Siswa menganalisis dari gambar yang ada tentang kemungkinan gaya geologi yang membentuk bentang alam tersebut, yang meliputi:nama bentangalamnya, lokasi atau daerah pada citra, dan dampak bentang alam tersebut bagi kehidupan manusia. Gambar dan deskripsi siswa kemudian dituangkan kedalam file powerpoint.

Pada sintaks-4 ini, ternyata ditemukan masalah bahwa sebagian besar siswa Kelas $X$ Geologi Pertambangan belum bisa menggunakan powerpoint secara baik. Hal ini menyebabkan guru selaku pelaksana penelitian akhirnya melakukan tutorial membuat file presentasi dalam format powerpoint. Tutorial yang singkat ini dapat diterima siswa, namun hasil pekerjaan siswa dalam membuat powerpoint tetaplah masih belumsesuai dengan harapan awal. Beruntung sebelum PTK berlangsung, guru sudah melakukan tutorial penggunaan aplikasi Google Earth. Jika tidak, maka bisa dipastikan bahwawaktu pada siklus-1 ini hanya akan habis untuk mengajarkan tutorial pembuatan powerpoint dan penggunaan Google Earth.

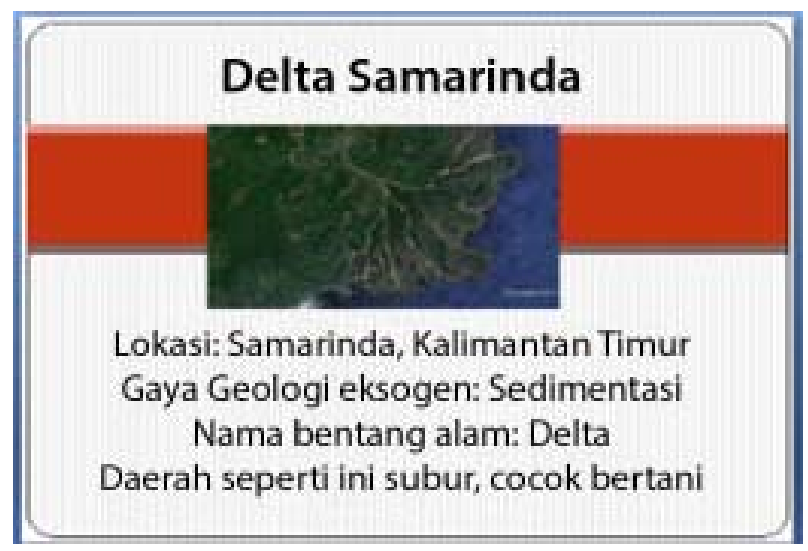

Gambar 4. Contoh Tampilan Powerpoint

Sintaks-5, siswa melakukan presentasi, salah satu anggota dalam setiap kelompok maju di depan kelas dan kemudian mempresentasikan hasil investigasi kelompoknya. Selanjutnya kelompok lain memberikan komentar. Komentar perlu diberi tanggapan atau jawaban dari kelompok yang sedang melakukan presentasi.

\section{Observasi}

Dari observasi yang dilakukan tercatat bahwa sebagian besar siswa (70\%) aktif melakukan investigasi dan analisis bentang alam bersama dengan kelompoknya. Namun, masih ditemukan efek free rider (siswa yang pasif) dalam kegiatan pembelajaran Siklus-1 ini. Catatan yang lain berkaitan dengan lokasi bentang alam, 90\% gambar citra yang diambil berada di Indonesia, sehingga variasi bentang alam yang ada sebagian kelompok sama. Hal ini juga diakibatkan karena 6 dari 8 kelompok memilih bentang alam hasil gaya endogen, sedangkan yang memilih gaya eksogen hanya 2 kelompok. 
Hasil data berpikir kritis siswa setelah melakukan pembelajaran pada Siklus-1 secara singkat dapat dilihat pada Tabel 2 berikut ini.

Tabel 2. Tingkat Berpikir Kritis Siswa (Siklus 1)

\begin{tabular}{|c|c|c|c|}
\hline $\begin{array}{c}\text { Klasifikasi } \\
\text { Nilai }\end{array}$ & $\begin{array}{c}\text { Kualifik } \\
\text { asi }\end{array}$ & $\begin{array}{c}\text { Frekuen } \\
\text { si }\end{array}$ & $\begin{array}{c}\text { Persentase } \\
(\%)\end{array}$ \\
\hline $\begin{array}{c}81,25<X< \\
100\end{array}$ & $\begin{array}{c}\text { Sangat } \\
\text { Kritis }\end{array}$ & 0 & 0 \\
\hline $\begin{array}{c}62,50<X< \\
81,25\end{array}$ & Kritis & 5 & 15 \\
\hline $\begin{array}{c}43,75<X< \\
62,50\end{array}$ & $\begin{array}{c}\text { Cukup } \\
\text { Kritis }\end{array}$ & 5 & 15 \\
\hline $\begin{array}{c}25<X 43,75 \\
\text { Jurang } \\
\text { Kritis }\end{array}$ & 23 & 70 \\
\hline \multicolumn{2}{|c|}{ Jumlah } & 33 & 100 \\
\hline
\end{tabular}

Berdasarkan Tabel 1, setelah melaksanakan pembelajaran siklus-1,tingkat berpikir kritis siswa berada pada kondisi kurang kritis. Hal ini menunjukkan bahwa pembelajaran GI tidak serta merta menjadikan siswa langsung meningkat keterampilan berpikir kritisnya.

\section{Refleksi}

Penggunaan model pembelajaran GI dan media pembelajaran Google Earth ternyata belum terbukti berhasil menjadikan siswa dapat berpikir kritis. Hasil ini perlu menjadi perhatian guru selaku peneliti dengan melakukan kilas balik dalam tahap perencanaan dan tindakan. Kemudian, hasil refleksi ini digunakan sebagai dasar memperbaiki perencanaan dan tindakan pada siklus berikutnya.

Dalam perencanaan, siswa dibebaskan untuk memilih gaya geologi yang akan diselidiki kelompok. Hal ini mengakibatkan kelompok tidak tertarik pada gaya geologi lain. Padahal dalam RPP yang dibuat, guru selaku peneliti membuat soal yang berisi kedua gaya geologi. Kelompok yang tidak menyelidiki atau membahas gaya geologi yang keluar pada soal tes berpikir kritis, otomatis tidak dapat menjawab soal dengan tepat. Dampaknya ternyata fatal bagi siswa yang memilih gaya endogenkarena apabila soal yang keluar merupakan gaya eksogen mereka tentulah tidak dapat mengerjakan soal tersebut secara baik, dan begitu juga sebaliknya.

Siswa hanya diminta mengambil gambar citra pada Google Earth. Hal ini tidak jauh berbeda dengan meminta siswa untuk browsing di internet dan kemudian mengunduh gambar contoh bentang alam hasil gaya geologi. Pada hal Google Earth memiliki kemampuan lain yang jauh lebih menarik daripada meminta siswa hanya mengumpulkan gambar.

Google Earth mampu melakukan perekaman sehingga bentangalam dapat dilihat dalam bentuk video. Bahkan Google Earth mampu untuk melakukan pencitraan secara historis (data temporal). Pencitraan secara historis akan mampu menerangkan perubahan bentangalam hasil gaya geologi seperti likuifaksi di Petobo, Sulawesi Tengah atau letusan Gunung Anak Krakatau yang kemudian menimbulkan tsunami di Selat Sunda.

\section{Siklus-2 (14 Februari 2019)}

\section{Identifikasi Masalah}

Masalah yang terjadi pada siklus-1 antara lain berupa: perencanaan dari guru yang membebaskan siswa memilih satu topik gaya geologi membuat siswa sama sekali tidak mempelajari gaya geologi yang lain, tugas yang diberikan guru dalam pemanfaatan Google Earth kurang menantang, keterampilan berpikir siswa masih banyak yang kurang kritis, keterampilan siswa menggunakan powerpoint masih rendah, masih ditemukan siswa yang pasif dalam pembelajaran. Adanya berbagai masalah di atas kemudian dijadikan alasan untuk melanjutkan PTK pada siklus-2.

Masalah yang muncul pada siklus-1 diusahakan tidak terjadi lagi pada siklus-2. Masalah tersebut dapat tidak muncul dengan cara memperbaiki perencanaan (menyusun RPP) yang digunakan pada siklus-2. Hal-hal yang menjadi kendala seperti penguasaan powerpoint diselesaikan melalui latihan secara mandiri oleh siswa di luar siklus PTK. 


\section{Perencanaan}

Penyusunan RPP pada Siklus-2 ini masih menggunakan model pembelajaran GI karena guru sebagai peneliti masih memiliki keyakinan model ini dapat meningkatkan keterampilan bepikir kritis siswa. Media pembelajaran juga masih menggunakan teknologi geospasial berupa Google Earth. Perbaikan pada RPP tahap satu ini adalah pada sintaks-3 GI, yang awalnya siswa hanya mengunduh citra Google Earth pada bentangalam menjadi siswa melakukan perekaman data temporal pada Google Earth.

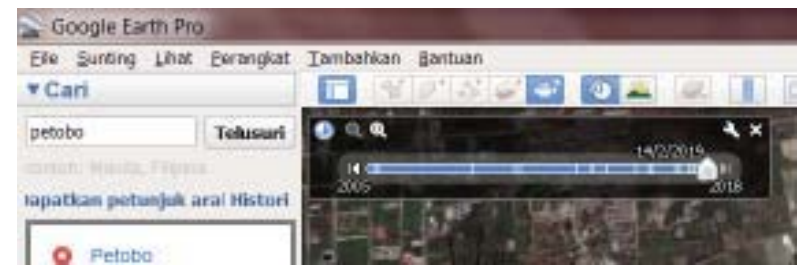

Gambar 5. Pengaturan Waktu untuk Menghasilkan Citra sebagai Data Temporal

Perekaman dilakukan dengan memadukan ikon bergambar jam dengan kamera. Perekaman bertujuan untuk merekam sebuah wilayah dalam citra Google Earth dengan memperhatikan perubahan waktu (lihat Gambar 5). Perekaman ini menghasilkan data temporal dari waktu-waktu tertentu. Siswa diharapkan dapat menganalisis perubahan bentangalam yang terjadi akibat gaya geologi. Gaya geologi yang dapat memanfaatkan hal tersebut seperti, menganalisis suatu wilayah sebelum dan setelah gempa bumi.

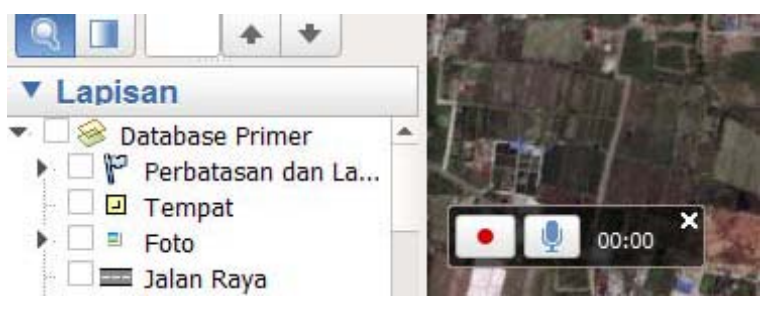

Gambar 6. Icon Perekaman untuk menghasilkan Video pada Google Earth

\section{Tindakan}

Siklus-2 ini menekankan tindakan yang dilakukan guru masih pada penggunaan model dan media pembelajaran yang sama pada siklus-1. Tindakan pada siklus-2 ini berbeda dengan siklus-1 dalam hal pengambilan citra Google Earth. Pengambilan citra pada siklus-2 memanfaatkan perekaman dan data keruangan berwaktu (data temporal).

Siswa yang awalnya bebas memilih gaya geologi yang membuat mereka tertarik akhirnya diminta untuk mencari semua jenis gaya geologi, baik endogen maupun eksogen. $\mathrm{Hal}$ ini dimaksudkan untuk menghindari terjadinya penguasaan materi secara setengah-setengah oleh siswa, yang menyebabkan soal berpikir kritis yang dibuat tidak dapat bekerja dengan baik. Tindakan pada siklus-2 diakhiri dengan tes.

Salah satu hasil yang ditampilkan oleh siswa dalam memanfaatkan Google Earth adalah Citra Petobo, Sulawesi Tengah yang mengalami gempa. Siswa melakukan perekaman pada waktu sebelum dan setelah terjadi gempa.

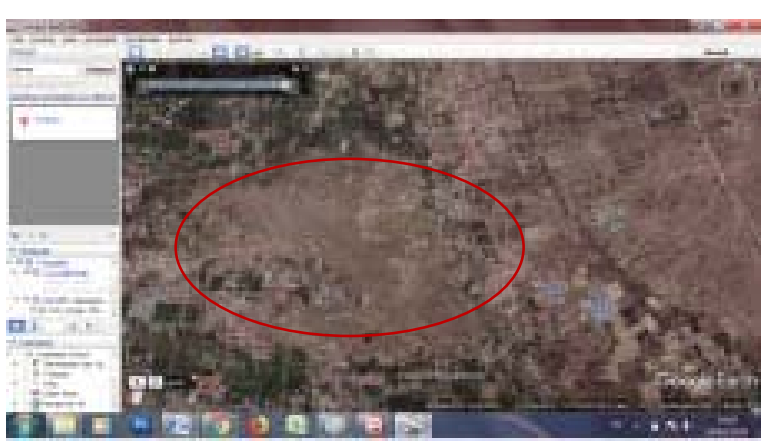

Gambar 6. Citra Wilayah Petobo Setelah Gempa (2 Oktober 2018)

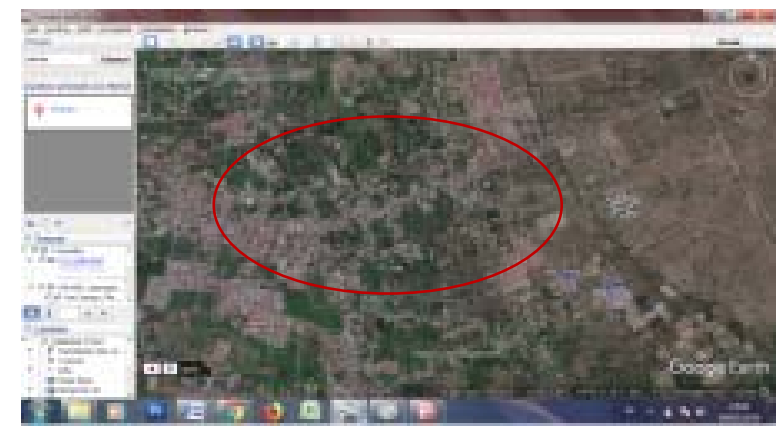

Gambar 7. Citra Wilayah Petobo Sebelum Gempa (2 Oktober 2018) 


\section{Observasi}

Pelaksanaan pembelajaran pada siklusII ini tampak membuat siswa lebih tertarik. Siswa antusias dalam memanfaatkan Google Earth. Sekalipun masih ada siswa yang pasif namun tetap mengikuti pekerjaan/tugas kelompoknya. Hal ini berarti efek free reader dalam pembelajaran berkelompok masih bisa diminimalisasi.

Kelompok sudah dapat melakukan perekaman secara baik meskipun demikian masih ditemukan adanya kelompok yang bertanya kepada guru tentang cara perekaman. Hal ini menjadi masalah bagi proses pembelajaran karena sebelumnya siswa sudah dilatih tentang pemanfaatan Google Earth. Ada pula kelompok yang masih belum dapat menggunakan powerpoint secara cermat. Padahal mereka sudah diminta untuk banyak belajar tentang powerpoint. Kedua hal ini mengandung arti bahwa penguasaan teknologi oleh siswa masih perlu mendapatkan perhatian serius.

Tingkat keterampilan berpikir kritis siswa dapat dilihat pada Tabel 3. Hasil ini menunjukkan bahwa sudah ada siswa yang berada pada tingkat berpikir sangat kritis, namun tetap ditemukan adanya siswa yang berada pada tingkat berpikir kurang kritis. Sebagian besar siswa sudah berada pada kualifikasi berpikir kritis.

Tabel 3. Tingkat Berpikir Kritis Siswa (Siklus-2)

\begin{tabular}{|c|c|c|c|}
\hline $\begin{array}{c}\text { Klasifikasi } \\
\text { Nilai }\end{array}$ & $\begin{array}{c}\text { Kualifika } \\
\text { si }\end{array}$ & $\begin{array}{c}\text { Frekuens } \\
\text { i }\end{array}$ & $\begin{array}{c}\text { Persenta } \\
\text { se (\%) }\end{array}$ \\
\hline $\begin{array}{c}81,25<X< \\
100\end{array}$ & $\begin{array}{c}\text { Sangat } \\
\text { Kritis }\end{array}$ & 3 & 9 \\
\hline $\begin{array}{c}62,50<X< \\
81,25\end{array}$ & Kritis & 15 & 46 \\
\hline $\begin{array}{c}43,75<X< \\
62,50\end{array}$ & $\begin{array}{c}\text { Cukup } \\
\text { Kritis }\end{array}$ & 11 & 33 \\
\hline $25<X 43,75$ & $\begin{array}{c}\text { Kurang } \\
\text { Kritis }\end{array}$ & 4 & 12 \\
\hline \multicolumn{2}{|c|}{ Jumlah } & 33 & 100 \\
\hline
\end{tabular}

\section{Refleksi}

Hal mendasar yang menjadi fokus dalam pelaksanaan pembelajaran GI berbantuan Google Earth adalah keterampilan berpikir kritis, penguasaan teknologi oleh siswa, dan keaktifan siswa selama proses pembelajaran berlangsung.
Ketiga hal ini terbukti saling terkait. Keterampilan berpikir kritis perlu mendapatkan dukungan penguasaan teknologi. Keterampilan berpikir kritis juga dapat dilakukan secara bersama-sama, dengan cara belajar kelompok. Hasil ini sejalan dengan penelitian Oktavianto, Handoyo, \& Sumarmi (2017) bahwa Google Earth dapat meningkatkan keterampilan berpikir siswa.

Siswa meskipun sudah terbiasa menggunakan gawai berupa ponsel pintar namun nyatanya masih ada yang gagap teknologi dalam memanfaatkan program presentasi powerpoint. Siswa juga masih ada yang belum terbiasa menggunakan Google Earth. Hal ini dapat menggambarkan bahwa penggunaan teknologi oleh siswa porsinya lebih banyak ke penggunaan ponsel pintar untuk game dan sosial media, meskipun ini perlu penelitian lebih lanjut.

GI tidak dapat membuat semua siswa aktif $100 \%$ dalam pembelajaran. Ada juga siswa yang masih pasif dalam pembelajaran. Ternyata efek free reader memang selalu muncul dalam pembelajaran kooperatif. Siswa mungkin sebaiknya diajarkan secara kooperatif dengan menggunakan satu perangkat komputer untuk satu orang siswa sehingga tiap tugas menjadi tanggung jawab masing-masing siswa. Hal ini mungkin akan berdampak pada peningkatan keaktifan siswa.

Keterampilan berpikir kritis siswa meningkat selama siklus-2. Hal ini membuktikan bahwa penugasan dari guru perlu dilakukan secara terencana, menantang, dan terukur. Pemanfaatan media pembelajaran berbasis teknologi geospasial terbukti mampu membuat anak lebih tertarik dalam belajar, eksplorasi dan eksploitasi teknologi untuk membantu siswa dalam belajar menumbuhkan motivasi siswa selama belajar. Hal ini sesuai dengan penelitian Demirci, Karaburun, \& Kilar (2013) yang menyatakan bahwa sebagian besar siswa yang belajar dengan Google Earth merasa proses pembelajarannya menyenangkan, bermanfaat dan menarik. Sejalan juga dengan hasil penelitian Blank, Almquist, Estrada, \& Crews (2016) mengakui bahwa pembelajaran berorientasi spasial seperti geologi, lebih mudah menarik perhatian siswa dengan bantuan Google Earth 


\section{SIMPULAN DAN SARAN}

\section{Simpulan}

Pemanfaatan media pembelajaran harus disesuaikan dengan model pembelajaran yang digunakan. Hal ini berlaku pula kebalikannya, yaitu penerapan model pembelajaran juga harus didukung oleh penggunaan media pembelajaran yang tepat. Teknologi geospasial seperti Google Earth dapat dimanfaatkan untuk peningkatan keterampilan berpikir kritis siswa dipadukan dengan model pembelajaran GI.

Terjadinya peningkatan keterampilan berpikir karena siswa mendapatkan media yang sesuai dengan tema (materi pelajaran) yang kali ini membahas tentang gaya geologi. Ini didukung adanya tugas yang menantang, seperti membuat video daripada hanya sekedar menyimpan gambar siswa menjadi lebih tertarik dalam belajar.

GI dan Google Earth secara bersamasama dapat meningkatkan keaktifan siswa dalam belajar. Meskipun demikian, masih ditemukan adanya siswa yang pasif. Hal ini memberikan arti bahwa efek free reader masih ditemukan dalam pembelajaran.

\section{Saran}

Penguasaan teknologi oleh siswa perlu ditingkatkan dengan cara memberikan tutorial di luar jam pelajaran kepada mereka. Kegiatan ini kemungkinan dapat dilakukan pada jam ekstra kurikuler. Keaktifan siswa dapat dirangsang dengan memberikan tugas yang menantang tetapi juga harus terukur dalam artian memperhatikan kemampuan siswa. Keterampilan berpikir kritis tidak serta merta dimiliki oleh siswa namun perlu perencanaan yang baik oleh guru, pemanfaatan teknologi, model pembelajaran yang sesuai, dan waktu yang relatif memadai.

\section{PUSTAKA ACUAN}

\section{Buku}

Halpern, D.F. (2013). Thought and Knowledge An Introduction to Critical Thinking. New
York: Psychology Press.

Slavin, R. E. (2015). Cooperative Learning, Theory Research and Pratice 2nd Ed. Boston: Ally Bacon Publisher.

Sumarmi. (2012).Model-Model Pembelajaran Geografi. Malang: Aditya Media.

Thibout, J. (2017). The Social Psychology of Groups. New York: Routledge.

\section{Jurnal/Prosiding/Disertasi/Tesis/Skripsi}

Agustin, A. (2017). Penggunaan Model Pembelajaran Group Investigation Untuk Meningkatkan Keterampilan Berpikir Kritis Peserta Didik SMA Negeri 1 Kotabaru. Tesis (tidak diterbitkan). Malang: UM http://karyailmiah.um.ac. id/index.php/disertasi/article/view/65285

Astra, I.M., Wahyuni, C., \& Nasbey, H. (2015). Improvment of Learning Process an Learning Outcome in Physic Learning by Using Collaborative Learning Model of Group Investigation at High School. Journal of Education and Practice, Vol. 6, No.11. hal. 75-79.

Bednarz, S., W. (2017). Using Action Research to Implement the National Geography Standard: Teacher Researchers.Journal of Geography, Vol. 101, No.3. hal.104-111.

Blank, L., Almquist, H., Estrada, J., \& Crews, J. (2016). Factors Affecting Students Success with a Google Earth-Based Earth Science Curriculum. Journal of Science Education and Technology 25 (1), hal. 77-99.

Demirci, A., Karaburun, A. \& Kilar, K. (2013). Using Google Earth as AnEducational Tool in Secondary School Geography Lessons.International Research in Geographical andEnvironmental Education Vol. 22 No. 4.hal 277-290.

Dwyer, C., Hogan, M., \& Stewart, I. (2014). An integrated critical thinking framework for the 21st century.Thinking Skills and Creativity. 12, hal 43-52.

Guertin, L. \& Neville, S. (2011). Utilizing Google Earth to Teach Students about Global Oil Spill Disasters. Science Activities Vol. 8.hal 1-8.(diunduh: 16 Juli 2017).

Hayuna, Budijanto \& Utomo. (2018). Pengaruh Problem-Based Learning (PBL) terhadap Keterampilan Berpikir Kritis. Jurnal Pendidikan: Teori, Penelitian, \& Pengembangan. http://journal.um. ac.id/ 
index.php/iptpp/article/view/10446

(diunduh: 26 Desember 2018).

Lin, P., Hou, H., Wang, S., \& Chang, K. (2013). Analyzing knowledge dimensions and cognitive process of a project-based online discussion instructional activity using Facebook in an adult and continuing education course. Computer \& Education, 60, hal.110-121.

Listiana, L. (2013). Pemberdayaan Keterampilan Berpikir dalam Pembelajaran Biologi melalui Model Kooperatif Tipe GI (Group Investigation) dan TTW (Think, Talk, Write). Artikel disampaikan pada Seminar Nasional Pendidikan Biologi FKIP UNS. (Online) https://eprints. uns.ac.id/8621/(diunduh: 16 Juli 2017).

Oktavianto, D.A., Handoyo, B., \& Sumarmi. (2017). Pengaruh Pembelajaran Berbasis Proyek Berbantuan Google Earth Terhadap Keterampilan Berpikir Kritis. Jurnal Teknodik. Vol. 21, No.1. Hal 59-69.

Oktavianto, D.A. \& Suyatno, S. (2018). Pengembangan Spatial Thinking On Map Test (STMT) Untuk Tingkat SMA. Jurnal Teknodik. Vol. 21, No. 1. Hal 73-74.

Pae, H., Sears, D., A. \& Maeda, Y. (2014). Effects of Small-Group Learning on Transfer: a Meta-Analysis. Educational Psychology Review. Vol. 27, No.1. Hal 79102.

Ratinen, I. \& Keinonen, T. (2011). Studentteachers' use of Google Earth in problembased geology learning. International Research in Geographical and Environmental Education Vol. 20 No. 4, hal 345-358.

Sari, Y., Jayanti, \& Jamil. (2016). Effect of PBL Learning Model on Critical Thinking Skills
Students Learning Course Design of Geography. Advances in Social Science, Education and Humanities Research, volume 79.hal. 316-319.

Sharan, Y. (2015). Meaningful learning in the cooperative classroom, Education 3-13. International Journal of Primary, Elementary and Early Years Education, 43(1), hal. 83-94.

Sidhu, E.P.\& Gilberto, C.(2018). Using Google Earth Engine To Detect Land Cover Change: Singapore as a Use Case. European Journal of Remote Sensing, 51:1, 486-500,

Stupple, E., Maratos, F., \& Elander, J. 2017. Development of the Critical Thinking Toolkit (CriTT): A measure of student attitudes and beliefs about critical thinking. Thinkings Skills and Creativity, 23, hal. 91-100.

Sudarsana, I., K. (2018). Pengaruuh Mode Pembelajaran Kooperatif Terhadap Peningkatan Mutu Hasil Belajar Siswa.Jurnal Penjaminan Mutu, Vol. 4, No.1, Hal.20-31.

Xiang, X., \& Liu, Y. (2016).Understanding change through spatial thinking using Google Earth in secondary geography. Journal of Computer Assisted Learning, Volume 33 (1), hal. 65-78.

Yu, L.\& Gong, P. (2012). Google Earth As A Virtual Globe Tool for Earth Science Applications at the Global Scale: Progress and Perspectives. International Journal of Remote Sensing, 33:12, 3966-3986.

\section{Lain-lain}

Brookhart, S. (2010). How to Assess Higher Order Thinking Skills in Your Classroom ASCD. http://www.ascd.org/Publications/Boo ks/Overview/How-to-Assess Higher-OrderThinking-Skills-in-Your-Classroom.aspx (diunduh: 16 Juli 2017). 